\title{
THE QUALITY OF OPENSTREETMAP IN MALAYSIA: A PRELIMINARY ASSESSMENT
}

\author{
S. N. R. M. Husen ${ }^{1}$, N.H. Idris ${ }^{1}$, M.H.I. Ishak ${ }^{2}$ \\ ${ }^{1}$ Department of Geoinformation, Faculty of Built Environment and Survey, Universiti Teknologi Malaysia, UTM Skudai, 81310, \\ Johor Bahru, Malaysia -roshi193@yahoo.com; hawani@utm.my \\ ${ }^{2}$ School of Electrical Engineering, Faculty of Engineering, Universiti Teknologi Malaysia, UTM Skudai, 81310, Johor Bahru, \\ Malaysia - hafis@utm.my
}

KEY WORDS: Volunteered Geographic Information, OpenStreetMap, Spatial Data Quality, Data Accuracy, Collaborative Mapping

\begin{abstract}
:
Over recent years, the phenomena, Web 2.0 has led to the growth of volunteered geographic information (VGI). The emergence of VGI has played an important role in providing timely data when the costs and its availability is a major concern particularly during emergency and humanitarian efforts. The worldwide crowdsourcing efforts through OpenStreetMap (OSM), the most successful open platform for collaborative mapping have managed to assist authorities such as during the 2017 Mexico earthquake and Hurricane Irma and Maria that impacted several countries in America continent. However, there are lots of arguments on the quality of VGI, particularly in regard to OpenStreetMap (OSM). Therefore, this study was carried out to assess the quality of OSM against authoritative sources using a dataset of Putrajaya, Malaysia. This study assessed the quality of OSM, including completeness, positional and thematic accuracy. From the preliminary assessment, the results showed that the OSM data was good in terms of relative positioning accuracy, particularly in road feature, but still poor in terms of completeness and thematic correctness against the reference dataset. This study is significant with an expected contribution to the assessment of quality of VGI in developing countries that commonly facing slow-paced progress in mapping the OSM. The findings could be used as a basis for various parties that plan to use OSM in Malaysia, particularly Putrajaya as a supplementary data to authoritative sources, including data supplied by the professional surveyors.
\end{abstract}

\section{INTRODUCTION}

Volunteered Geographic Information (VGI) is a result of the growing range of interactions enabled by the evolving web. Volunteered Geographic Information (VGI) is a term coined by Goodchild (2007) as a process of collecting spatial data by individuals, most times on a voluntary basis. It denotes to "geospatial data that are voluntarily created by citizens who are untrained in the disciplines of geography, cartography or related fields" (Seeger, 2008). In some cases, VGI is the cheapest and only source of geo-information, particularly when access to geographic information is considered an issue of national security (Neis and Zielstra, 2014). Producing maps and geographic information by non-expert citizens who do not have the professional qualifications associated with geospatial analysis are known by different terms, such as Neogeography, Ubiquitous cartography, and VGI (Esmaili et al., 2013), although basically they are referring to similar phenomena.

VGI has been used in various contexts. National and regional mapping agencies are increasingly obtaining benefit from VGI. There are several reasons for producing VGI, such as usage as a base map, emergency reports, and in citizen science programmes as it was widely used in scientific studies. The worldwide crowdsourcing efforts through OpenStreetMap (OSM) have managed to assist authorities such as during the 2017 Mexico earthquake and Hurricane Irma and Maria that severely impacted several countries bordering the Atlantic Ocean (OpenStreetMap Wiki contributors, 2017). OSM aims to provide a free digital map of the world through volunteers' efforts. The data is collected by many volunteers around the globe and collectively stored in a central database, then distributed in multiple digital formats through the World Wide Web (Haklay, 2010).

There are several online mapping applications that serve as VGI platforms, including Wikimapia and Google Map Maker, though OSM is currently the active platform, particularly in developed countries. In Malaysia, the concept of VGI was introduced in Malaysia for more than a decade when the early participatory mapping was initiated by a local NGO in 1994 (Idris et al., 2016). Nevertheless, the effort of OpenStreetMap (OSM) was slowly started in Malaysia in late 2011, when only four users were registered at that time (OSMStats, 2017). The OSM efforts in London was started seven years earlier, which in August 2004 (Haklay, 2008). At present, the Germany has the highest number of OSM members and Zimbabwe has the highest number of created nodes (OSMStats, 2017) though United States has been claimed as having the highest coverage of OSM data due to the availability of TIGER/Line import tool in OSM platform (Zielstra and Hochmair, 2011).

The increasing popularity of OSM prompted to a considerable number of researchers to investigate its data quality. Most of early studies were focused on European OSM datasets. For example, Haklay (2008) assesses the positional accuracy and completeness of OSM in London and demonstrated the road networks as fairly accurate with $80 \%$ of overlap with the reference datasets. Similarly a study is conducted by Kounadi 
(2009) compares OSM with the Hellenic Military Geographical Service (HMGS) datasets and found out most OSM roads were in good quality. In French, Girres and Touya (2010) compared the OSM data with datasets from the French National Mapping Agency. The study showed that the quality of OSM dataset was heterogeneous due to a lack of standardized and precise specification that would allow contributors to provide good quality data. Nies et al. (2012) assessed the quality of road networks in German OSM datasets and found out the total length of road networks have exceeded the commercialTomTom dataset especially in high population area. Zielstra and Hochmair (2011) have assessed the quality of OSM dataset in outside Europe where they have identified different patterns of OSM in United States. The dataset shows high coverage in rural compared to urban area due to the availability of open source data from US Census Bureau and US Geological survey that could be imported into OSM platform.

Several studies have been devoted to assess the quality of OSM in developing countries. For example, in South Africa, Siebritz (2015) identified heterogonous quality across study area where more developed area received more contributions than low urban density area. In Indonesia, Aditya et al. (2012) assessed the quality of OSM datasets and identified variation of quality from good to poor across the five cities that were assessed. The OSM efforts in developing countries are progressing at a slowpaced where motivation to contribute is still lower compared to the European countries (Sehra et al., 2012). High concentration of OSM members influences the coverage and quality of OSM datasets for the countries (Neis et al., 2013). In Malaysia, OSM dataset is commonly used as a base map to support the top layer data as it is freely embedded with web mapping platforms such as ArcGIS Online, QGIS, 1MalaysiaMap (www.mygeoportal.gov.my/). OSM dataset is also embedded in Ushahidi platform (www.ushahidi.com) that commonly used for disaster and crisis management. Idris et al. (2016) have highlighted the missing of road networks and names in OSM Malaysia particularly in suburban and urban area that led to a difficulty to locate point of interests during disaster through Ushahidi platform.

Therefore, this paper discusses the quality of OSM dataset in Malaysia, evaluating its positional accuracy, thematic correctness and completeness of dataset against authoritative dataset. This study assessed the quality of OSM dataset in Malaysia that focus on Putrajaya area, a Federal Territory that has been established as the Malaysia federal government administrative center after shifted from Kuala Lumpur in 1999.

\section{METHODOLOGY}

This study applied extrinsic OSM assessment, in which OSM and reference data can be compared to one another (Jacobs and Zipf, 2017). The external data source that obtained from the Perbadanan Putrajaya (PPJ) was considered as spatially complete. Quality can be defined as the "fitness for purpose" which practically means the suitability of data for solving problems with specific requirements (Coote and Rackham, 2008). According to ISO 19157 standard (2013), there are six spatial data quality elements that could be measured including data completeness, logical consistency, positional accuracy, thematic accuracy, temporal quality and usability element.
However this study focussed on the common quality elements in assessing OSM dataset (for example see Haklay, 2008; Nies et al., 2012) that assessed the completeness, positional and attribute consistency of OSM dataset with authoritative sources.

\subsection{Study area and data preparation}

The study area used in this study is the Federal Territory of Putrajaya, Malaysia, a Federal Government Administrative Centre managed and administered by Perbadanan Putrajaya (Putrajaya Corporation). Putrajaya is the new federal government administrative center in Malaysia. Putrajaya is well structure developed as an intelligent city to facilitate communications and interactions between government office, business and the community. Putrajaya covers an area of 4931 hectares of land and about $25 \mathrm{~km}$ from Kuala Lumpur.

The OSM data sets of Putrajaya that covered from May 2014 to December 2016 were converted into shapefile format and visualised in ArcGIS software. The reference vector data that were originally projected in custom Cassini coordinate system, namely Putrajaya Grid (in shapefile format) were obtained from the local authority that administers the Federal Territory of Putrajaya, namely Perbadanan Putrajaya (PPJ).

For comparison, both data were projected onto the Rectified Skewed Orthomorphic (RSO) projection. Before conducting the quality assessment, the OSM data were pre-processed as below

1) Filtering - The attributes of road and building features were extracted from the OSM datasets.

2) Feature matching - Corresponding roads and polygon features between the PPJ and OSM data were identified based on the semantic keywords as shown in Table 1 and 2 respectively.

\begin{tabular}{|l|l|l|}
\hline $\begin{array}{l}\text { Perbadanan } \\
\text { Putrajaya } \\
\text { Data }\end{array}$ & $\begin{array}{l}\text { OpenStreetMap } \\
\text { Data }\end{array}$ & $\begin{array}{l}\text { Matched } \\
\text { Keywords }\end{array}$ \\
\hline Primary & Motorway/ Primary & Primary Road \\
\hline $\begin{array}{l}\text { Spine } \\
\text { Local }\end{array}$ & Secondary/ Tertiary & $\begin{array}{l}\text { Secondary } \\
\text { Road }\end{array}$ \\
\hline Residential & $\begin{array}{l}\text { Residential/ Living } \\
\text { Street }\end{array}$ & $\begin{array}{l}\text { Residential } \\
\text { Road }\end{array}$ \\
\hline
\end{tabular}

Table 1: Semantic matching between OSM and PPJ roads

\begin{tabular}{|l|l|l|}
\hline $\begin{array}{l}\text { Perbadanan } \\
\text { Putrajaya } \\
\text { Data }\end{array}$ & $\begin{array}{l}\text { OpenStreetMap } \\
\text { Data }\end{array}$ & $\begin{array}{l}\text { Matched } \\
\text { Keywords }\end{array}$ \\
\hline $\begin{array}{l}\text { Institutional } \\
\text { Building }\end{array}$ & Office & $\begin{array}{l}\text { Institutional } \\
\text { Building }\end{array}$ \\
\hline $\begin{array}{l}\text { Residential } \\
\text { Building }\end{array}$ & $\begin{array}{l}\text { Apartments,Terrace, } \\
\text { Residential }\end{array}$ & $\begin{array}{l}\text { Residential } \\
\text { Building }\end{array}$ \\
\hline $\begin{array}{l}\text { Commercial } \\
\text { Building }\end{array}$ & Commercial, Hotel & $\begin{array}{l}\text { Commercial } \\
\text { Building }\end{array}$ \\
\hline $\begin{array}{l}\text { Education } \\
\text { Building }\end{array}$ & School & $\begin{array}{l}\text { Education } \\
\text { Building }\end{array}$ \\
\hline $\begin{array}{l}\text { Worship } \\
\text { Building }\end{array}$ & Mosque & $\begin{array}{l}\text { Worship } \\
\text { Building }\end{array}$ \\
\hline
\end{tabular}




\begin{tabular}{|l|l|l|}
\hline $\begin{array}{l}\text { Medical } \\
\text { Centre }\end{array}$ & Hospital & Medical Centre \\
\hline Lakes & Water & Lake \\
\hline Police Station & Police & Police Station \\
\hline
\end{tabular}

Table 2: Semantic matching between OSM and PPJ polygon features

\subsection{Calculating the positional accuracy of features}

Positional accuracy is the assessment of position of features where relative positional accuracy is the closeness of the relative positions of features to their respective relative positions (ISO19115, 2005). The method by Goodchild and Hunter (1997) was chosen to compute the positional accuracy of road features in this study. By using this method, the accuracy is determined by the percentage of OSM road that is within the buffer of the corresponding PPJ road feature. There were 180 road segments were assessed to identify the percentage of overlap of PPJ data. The 180 road segments were divided distinctively into three types of road types, namely primary, secondary, and residential roads. As the PPJ represents the two directions as a single line, this study used different sizes of buffer around different roads. By referring to the national road specification, (JPBD, 2007), the primary, secondary and residential road of PPJ dataset were buffered 7 meter, 6.6 meter and 5.6 meter respectively. Then, the data were overlaid with OSM roads to compute the overlap percentage by using equation (1) (Goodchild and Hunter, 1997) as follow;

100 Overlap $\%=$ (length of tested dataset lies within the buffer/ total length of tested dataset)*100

Meanwhile, for compute the overlap of polygon features, this study used the equation (2) as follow;

Overlap $\%=(($ area intersect $/$ buffer area of OSM road selected $)$ $* 100)$

The relative positional accuracy was also computed by calculating the root mean square error (RMSE) of two coordinates (points A to B) of same features in both datasets by using equation (3) (MaCGDI, 2010). The 137 points were selected as a sample of OSM road features and 157 points were selected as a sample for building features for calculating the positional error as shown in Figure 1 and 2 respectively. SDA (Spatial Data Accuracy) = RMSE x 1.2816

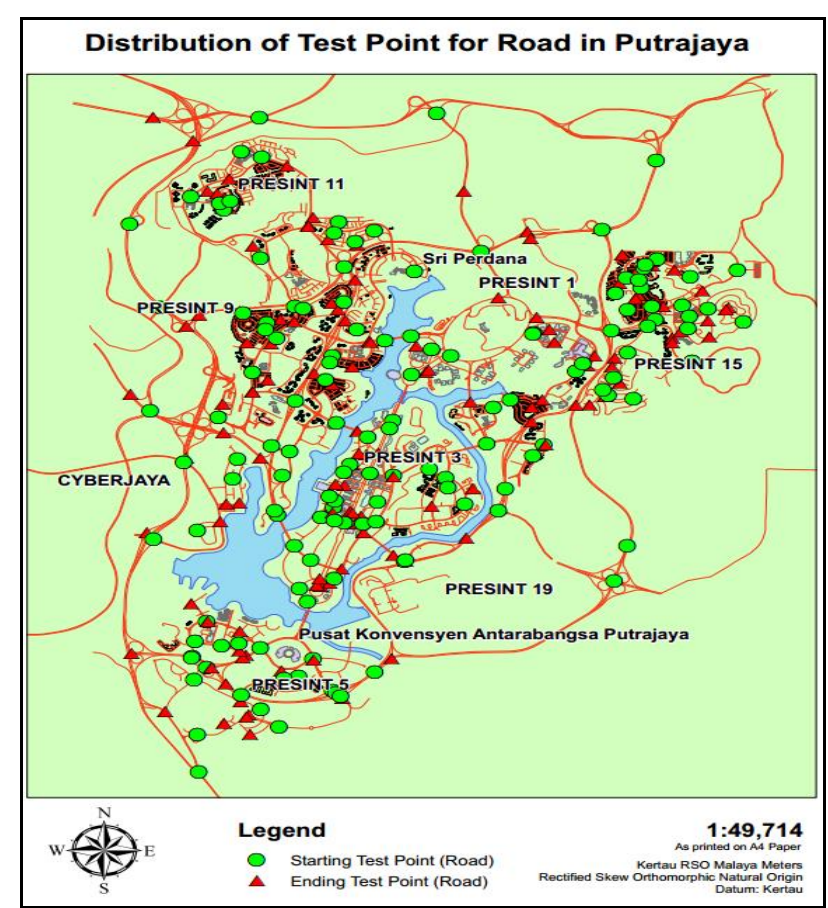

Figure 1: The distribution of sample pair of points for calculating the positional errors of road features

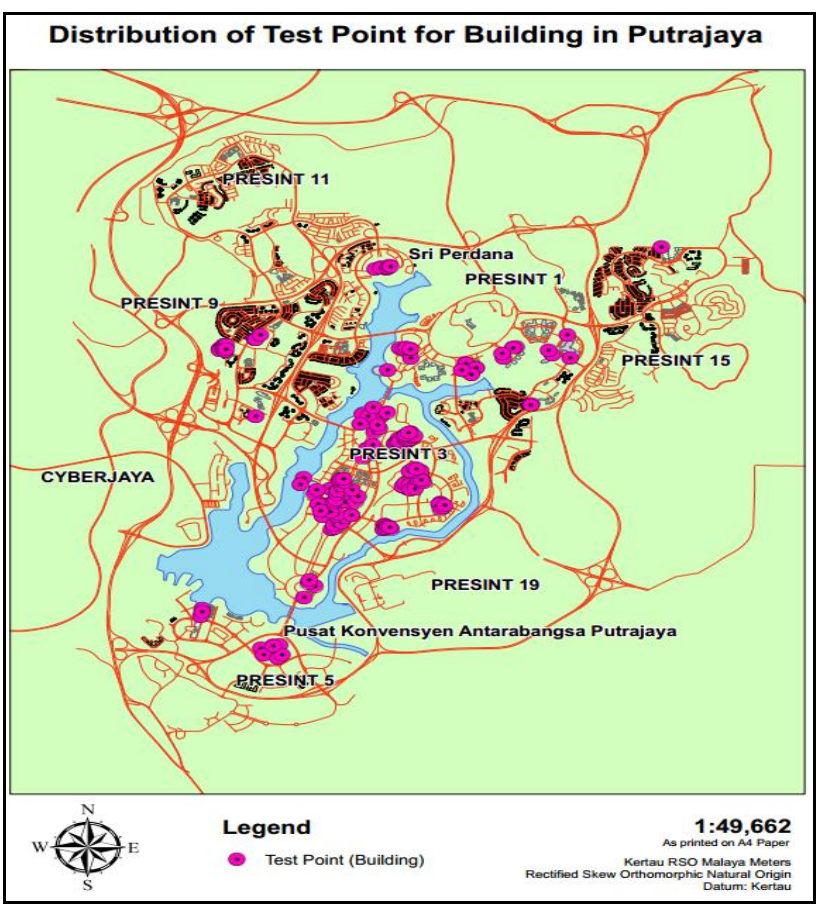

Figure 2: The distribution of sample pair of points for calculating the positional errors of building features

\subsection{Calculating the completeness of features}

Road network and building and lake features of both datasets were overlaid and the percentage of were calculated using equation (4) (Kounadi, 2009);

Completeness $\%=((\mathrm{OSM}$ number of feature $/ \mathrm{PPJ}$ number of feature) $*$ 100) (4)

2.4 Calculating the thematic accuracy of features 
In this study, the correctness of road class was calculated by comparing the length of road with the correct 'type of road' against PPJ dataset using equation (5) as below as below (Kounadi, 2009);

$$
\text { Correctness } \%=((\mathrm{A} / \mathrm{B}) * 100)
$$

Where,

A = OSM road length with correct class

\section{$\mathrm{B}=\mathrm{OSM}$ total road length}

The correctness of road and polygon features' names were calculated by by comparing the correct number of feature name against PPJ dataset as equation (6) as below (Kounadi, 2009);

$$
\text { Correctness }=((\mathrm{C} / \mathrm{D}) * 100)
$$

Where,

$\mathrm{C}=$ number of the features with correct name

$\mathrm{D}=$ total number of OSM features

\section{RESULTS AND DISCUSSIONS}

\subsection{Positional accuracy of roads}

Of the 180 road segments that were buffered, the overlap percentage of roads that was overlap is $94 \%$, which indicates that the positional accuracy of road segments in OSM is good. This percentage is nearly comparable to the positional accuracy of road segment in London that demonstrated as $80 \%$ overlap by Haklay (2008). As shown in Table 3, there are a total of 60 road segments that for each category where secondary roads and residential road show good quality compared to primary roads, though the differences are not significant. However it is worth to highlight the relative positioning of road features in urban area is of higher quality than suburban area, particularly in primary road feature. The relative positional accuracy of 137 roads that were calculated by using equation (1) indicates the error (RMSE) between OSM and reference dataset was +- 0.72 meters. Figure 3 shows a snapshot of overlap between two buffered roads.

\begin{tabular}{|l|l|l|l|}
\hline Road Type & $\begin{array}{l}\text { Primary } \\
\text { Road }\end{array}$ & $\begin{array}{l}\text { Secondary } \\
\text { Road }\end{array}$ & $\begin{array}{l}\text { Residential } \\
\text { Road }\end{array}$ \\
\hline Number of roads & 60 & 60 & 60 \\
\hline Urban District & 30 & 30 & 30 \\
\hline $\begin{array}{l}\text { Suburban } \\
\text { District }\end{array}$ & 30 & 30 & 30 \\
\hline $\begin{array}{l}\text { Average for } \\
\text { Overlap } \\
\text { Urban District }\end{array}$ & $98.82 \%$ & $96.74 \%$ & $98.53 \%$ \\
\hline $\begin{array}{l}\text { Average for } \\
\text { Overlap } \\
\text { Suburban for } \\
\text { District }\end{array}$ & $85.06 \%$ & $93.76 \%$ & $93.41 \%$ \\
\hline $\begin{array}{l}\text { Total Average } \\
\text { Overlap }\end{array}$ & $91.95 \%$ & $95.25 \%$ & $95.46 \%$ \\
\hline $\begin{array}{l}\text { Total Overlap } \\
\text { Tate } \% \text { Con } \%\end{array}$ \\
\hline
\end{tabular}

Table 3: Comparison of overlaps according to the type of roads

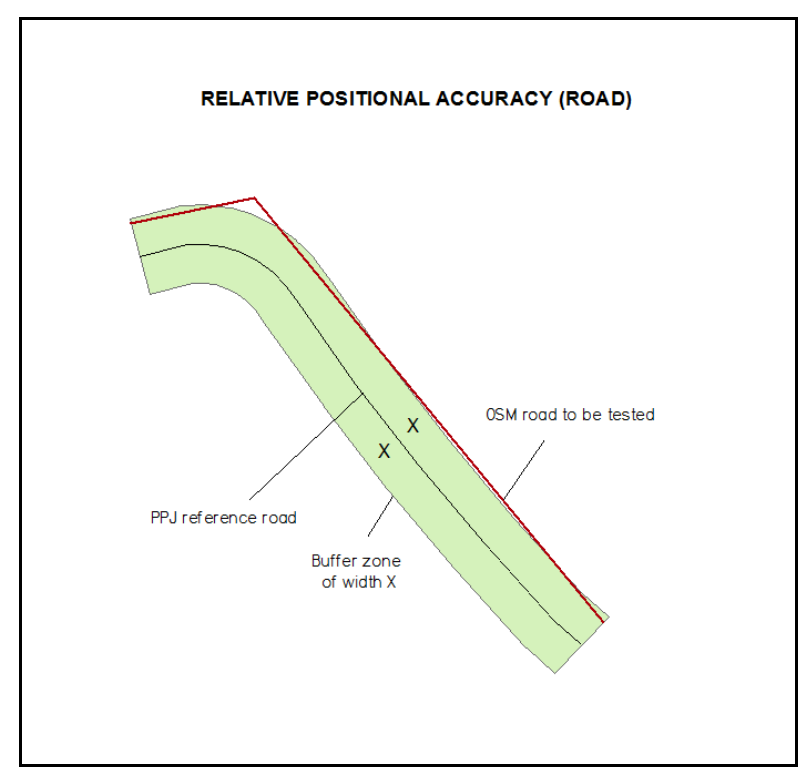

Figure 3: A snapshot of overlap between two roads

\subsection{Positional accuracy of polygon features}

The positional accuracy for polygon features in OSM is fairly good which is $70 \%$. Table 4 shows the percentage of overlap using equation (2). From the Table 4, worship buildings and lakes have the highest percentage overlap. As differences of digitization style by various users may influence to the percentage of overlap between objects (Saiful, 2012). Some users may digitize exactly on top of the building according to the shape of the building, while the rests may digitize it without following the exact shape of the building. The relative positional accuracy of 157 polygon features that were calculated by using equation (3) indicates the error (RMSE) between OSM and reference dataset was +- 1.49 meters.

\begin{tabular}{|l|l|}
\hline Polygon Features & $\begin{array}{l}\text { Percentage } \\
\text { Overlap }\end{array}$ \\
\hline Residential Building & $65.4 \%$ \\
\hline Commercial Building & $73.3 \%$ \\
\hline Worship Building & $88.6 \%$ \\
\hline Medical Centre & $60.1 \%$ \\
\hline Institutional Building & $73.3 \%$ \\
\hline Educational Building & $31.4 \%$ \\
\hline Lakes & $94.4 \%$ \\
\hline
\end{tabular}

Table 4: Comparison of overlaps according to the different type of polygon features 


\subsection{Completeness}

Completeness measures the absence of data and the presence of excess data (Oort, 2006). This study assesses the completeness of road and polygon (i.e. building) features. By assessing completeness, we can identify which areas that are well covered and which area that need further work by the OSM community (Haklay, 2008). The total length of OSM roads was compared with the reference data. The OSM road networks is 638.6 kilometres in length and PPJ road network is 716.56 kilometres. The OSM network is only $11 \%$ less complete than PPJ network. Figure 4 shows the overlaying of OSM on top of PPJ datasets, which displays areas with omitted data. From visual inspection, complete road networks are demonstrated in Precinct 1, 2, 3, 18, and 20 while in precinct 5 and 9 demonstrated as almost complete. Precinct 12 and 16 shows the lowest in terms of completeness. Generally, the completeness of OSM data is very good with a percentage of $89 \%$. Most of the complete roads are primary roads whereas incomplete roads are residential roads. This is in line with the study by Neis et al. (2012) that indicates majority of the unnamed streets are streets that are either within or close to residential areas.

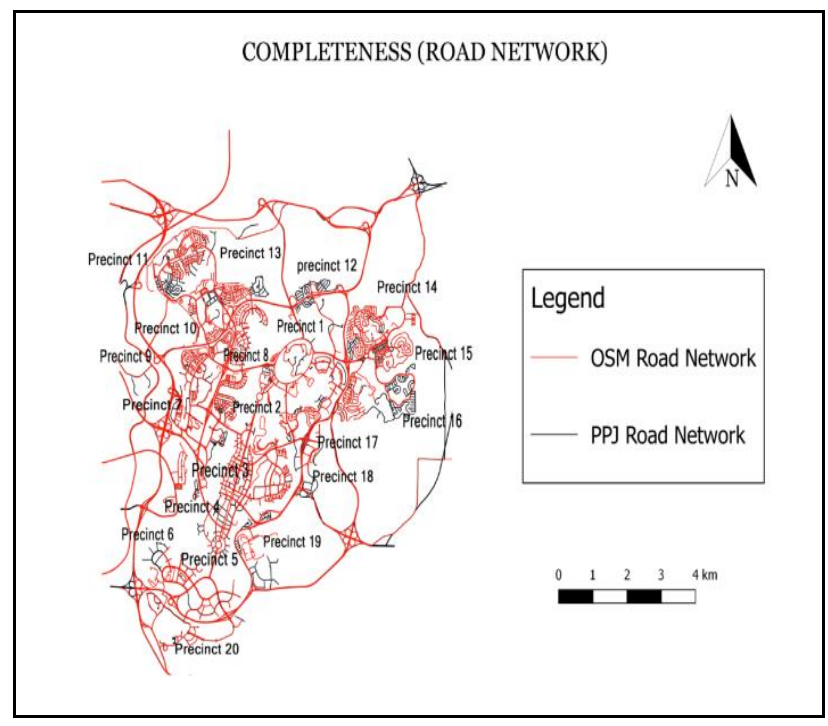

Figure 4: Completeness of road network

From Table 5, the road name completeness shows that only $59 \%$ of roads are labelled where the rests of names for roads $(41 \%)$ in OSM datasets are missing. Figure 5 shows the OSM road networks map with correctly attributed names and vice versa. It can be seen that most of the road names are incomplete. Higher number of roads was labelled in Precinct 14. The percentage of name completeness is low, though the completeness according to the total road length is high. Most of the labelled roads were primary roads. The reasons might be due to the practice of OSM contributors of not editing the attributes while digitizing the roads. They might not know the local name of the road they digitized, especially when the data have been digitized from satellite images (Neis et al., 2012). Kounadi (2009) also argue the approach used by volunteers to upload data might influence to this issue. This is because if volunteers collect data using a GPS device, then they can note down the name of the roads and add the information during the editing process; however if they adding attribute names by referring to commercial maps such as Microsoft Bing Map, there is a restriction due to the copyright laws.

\begin{tabular}{|l|l|l|}
\hline $\begin{array}{l}\text { Total road length } \\
\text { of OSM }\end{array}$ & $\begin{array}{l}\text { Total road } \\
\text { length of } \\
\text { PPJ }\end{array}$ & $\begin{array}{l}\text { Percentage of road } \\
\text { name completeness }\end{array}$ \\
\hline 391.05 & 662.6 & $59 \%$ \\
\hline
\end{tabular}

Table 5: Analysis of road name completeness

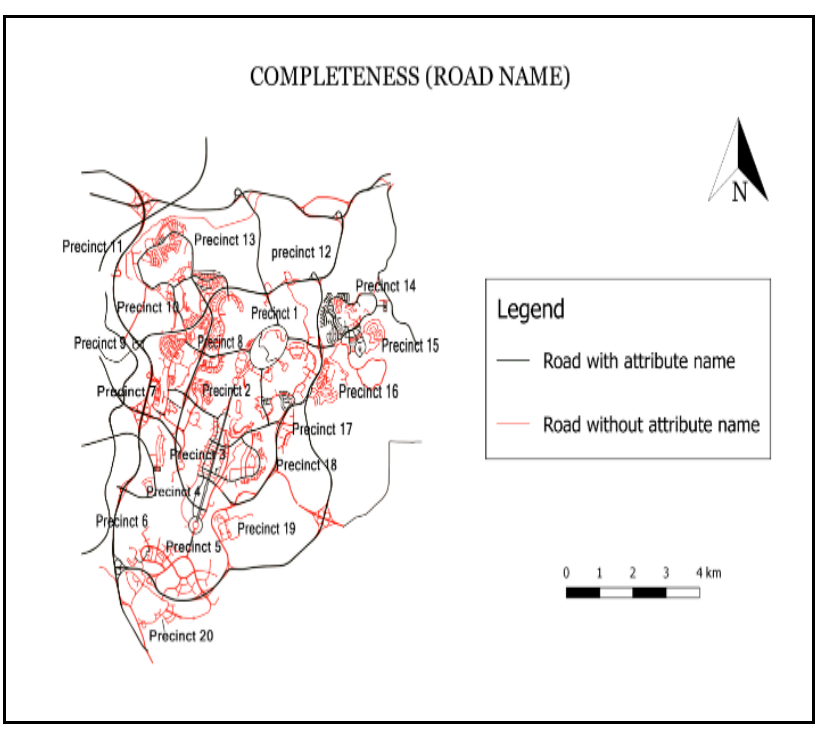

Figure 5: Completeness of road names

Completeness assessment of polygon features shows that only $2 \%$ are digitized as shown in Table 6. This shows that volunteers might not focussed in digitizing the building features. More than $95 \%$ polygon features are omitted in OSM compared to PPJ datasets. From Table 7 and Table 8, residential buildings show the lowest number of completeness. Out of 4,239 residential buildings in PPJ datasets, only 25 buildings were digitized by OSM volunteers and mostly focused in Precinct 18. In contrast, medical centres and lakes were completely digitized. There are $54 \%$ of features that represent institutional buildings mapped in OSM where the precincts (i.e. Precinct 1, 2, 3, 4 and 10) that allocated for government administrative buildings are completely mapped. From Table 9, many residential, educational, and commercial buildings are missing in OSM dataset as their percentage of completeness is very low. From our visual inspection, the completeness of commercial buildings was high at Precinct 2, 3, 4 and 5, the areas that located many federal administrative buildings and popular tourist area including the Prime Minister's office and Putra Mosque. This study also found out the precincts that still incomplete in OSM was in the suburban area (e.g. Precinct 8 and 11) and in the area that is located between the boundaries of Putrajaya (e.g. Precinct 5). This is in line with the findings by Haklay (2008) that stated there is a decrement of OSM quality particularly in the outskirt of city due to not well covered by OSM volunteers. 


\begin{tabular}{|l|l|l|}
\hline $\begin{array}{l}\text { Total area of } \\
\text { polygon features } \\
\text { in OSM }\left(\mathbf{k m}^{\mathbf{2}}\right)\end{array}$ & $\begin{array}{l}\text { Total area of } \\
\text { polygon features in } \\
\left.\text { PPJ } \mathbf{( k m}^{\mathbf{2}}\right)\end{array}$ & $\begin{array}{l}\text { Percentage of } \\
\text { completeness }\end{array}$ \\
\hline 89 & 5049 & $2 \%$ \\
\hline
\end{tabular}

Table 6: The comparison of features completeness

\begin{tabular}{|l|l|l|l|}
\hline Features & $\begin{array}{l}\text { Total } \\
\text { OSM } \\
\text { number of } \\
\text { building }\end{array}$ & $\begin{array}{l}\text { Total PPJ } \\
\text { number of } \\
\text { building }\end{array}$ & $\begin{array}{l}\text { Percentage of } \\
\text { feature } \\
\text { completeness }\end{array}$ \\
\hline $\begin{array}{l}\text { Residential } \\
\text { Building }\end{array}$ & 25 & 4239 & $0.6 \%$ \\
\hline $\begin{array}{l}\text { Institutional } \\
\text { Building }\end{array}$ & 41 & 76 & $54 \%$ \\
\hline $\begin{array}{l}\text { Education } \\
\text { Building }\end{array}$ & 2 & 166 & $1.2 \%$ \\
\hline $\begin{array}{l}\text { Medical } \\
\text { Centre }\end{array}$ & 1 & 1 & $100 \%$ \\
\hline $\begin{array}{l}\text { Worship } \\
\text { Building }\end{array}$ & 3 & 9 & $33.3 \%$ \\
\hline $\begin{array}{l}\text { Commercial } \\
\text { Building }\end{array}$ & 12 & 553 & $2.2 \%$ \\
\hline Lake & 5 & 5 & $100 \%$ \\
\hline
\end{tabular}

Table 7: Completeness of building features section one

\begin{tabular}{|l|l|l|l|}
\hline Features & $\begin{array}{l}\text { Total area } \\
\text { in OSM } \\
\text { (km2) }\end{array}$ & $\begin{array}{l}\text { Total area } \\
\text { in PPJ } \\
\text { (km2) }\end{array}$ & $\begin{array}{l}\text { Percentage } \\
\text { area } \\
\text { completeness }\end{array}$ \\
\hline $\begin{array}{l}\text { Residential } \\
\text { Building }\end{array}$ & 60897.4 & 695177 & $8.7 \%$ \\
\hline $\begin{array}{l}\text { Institutional } \\
\text { Building }\end{array}$ & 358238 & 374854 & $95.6 \%$ \\
\hline $\begin{array}{l}\text { Education } \\
\text { Building }\end{array}$ & 96759.7 & 142121 & $68.1 \%$ \\
\hline $\begin{array}{l}\text { Medical } \\
\text { Centre }\end{array}$ & 14610.3 & 14616.9 & $99.9 \%$ \\
\hline $\begin{array}{l}\text { Worship } \\
\text { Building }\end{array}$ & 39667.5 & 43780.5 & $90.6 \%$ \\
\hline $\begin{array}{l}\text { Commercial } \\
\text { Building }\end{array}$ & 175179 & 257888 & $67.9 \%$ \\
\hline Lake & 3857155.53 & 3885628.75 & $99.3 \%$ \\
\hline
\end{tabular}

Table 8: Completeness of building features section

\subsection{Thematic Accuracy}

Thematic accuracy can be measured by computing the accuracy and correctness of the attributes and of the classification of features and their relationship (ISO 19115, 2005). This study assesses the correctness of road classes and names. Table 9 shows that only $41 \%$ of OSM roads are classified correctly and matched with the PPJ reference dataset. A total of $5.7 \%$ of primary roads and secondary roads are misclassified as secondary and tertiary roads, respectively. Roads classified as residential show a higher percentage of roads with the correct classification type. In contrast, roads classified as a primary road show a lower percentage of correctly classified. One reason might due to OSM contributors seem unsure about the road type, either "tertiary", "unclassified" or "residential", hence they usually prefer to leave the 'road type' as blank code, which results in it appearing as unclassified on the OSM map. It also might be due to lack of knowledge on the area they choose to digitize.

\begin{tabular}{|l|l|l|l|}
\hline $\begin{array}{l}\text { Type of } \\
\text { roads }\end{array}$ & $\begin{array}{l}\text { Length of OSM } \\
\text { roads with correct } \\
\text { classification }(\mathbf{k m})\end{array}$ & $\begin{array}{l}\text { Total } \\
\text { road } \\
\text { length } \\
\mathbf{( k m )}\end{array}$ & $\begin{array}{l}\text { Percentage } \\
(\boldsymbol{\%})\end{array}$ \\
\hline Primary & 102.68 & $\begin{array}{l}326.5 \\
7\end{array}$ & 31.4 \\
\hline Secondary & 37.87 & 77.71 & 48.7 \\
\hline $\begin{array}{l}\text { Residentia } \\
1\end{array}$ & 119.33 & $\begin{array}{l}219.1 \\
3\end{array}$ & 54.5 \\
\hline & Total $=259.88$ & $\begin{array}{l}623.4 \\
1\end{array}$ & 44.8 \\
\hline
\end{tabular}

Table 9: The percentage of correctly classified roads according to the type of road

The percentage of roads with correct attributes resulted in $30 \%$ of overall road segments in OSM. Out of $638.36 \mathrm{~km}$ total length of OSM roads, only $191.9 \mathrm{~km}$ were named correctly, while the rest were incorrect. In general, the correctness of the road names was low. Table 10 shows a sample of roads that were misnamed. The factor for misnamed roads might be due to the fallacy mistakes by OSM contributors in obtaining the road name while doing fieldwork (Saiful, 2012).

\begin{tabular}{|l|l|}
\hline $\begin{array}{l}\text { Incorrect names in } \\
\text { OSM dataset }\end{array}$ & $\begin{array}{l}\text { As in the reference (PPJ) } \\
\text { dataset }\end{array}$ \\
\hline Lebuh Wadi Ehsan & Persiaran Timur \\
\hline Putrajaya Link & Persiaran Barat \\
\hline Lebuh Sentosa & Lebuh Saujana \\
\hline Jalan Kemerdekaan & Jalan P18 \\
\hline
\end{tabular}

Table 10: A sample of incorrect road names for OSM dataset

Overall, the percentage of building features with correct attributes was $28 \%$. This shows that more than half of the attributed 'name' fields were blank. Most of the attributes were left blank and only a few were mismatched with the PPJ dataset. Based on Table 11, residential buildings showed zero percentage as most of the residential buildings were left blank whereas a few of them were incorrectly named. 


\begin{tabular}{|l|l|l|l|}
\hline Features & $\begin{array}{l}\text { Total number } \\
\text { of features in } \\
\text { OSM with } \\
\text { correct } \\
\text { attribute } \\
\text { name }\end{array}$ & $\begin{array}{l}\text { Total } \\
\text { number } \\
\text { of } \\
\text { features } \\
\text { in OSM }\end{array}$ & $\begin{array}{l}\text { Percentage } \\
\text { of features } \\
\text { with correct } \\
\text { attribute } \\
\text { name }\end{array}$ \\
\hline $\begin{array}{l}\text { Residential } \\
\text { Building }\end{array}$ & 0 & 25 & $0 \%$ \\
\hline $\begin{array}{l}\text { Institutional } \\
\text { Building }\end{array}$ & 13 & 41 & $71 \%$ \\
\hline $\begin{array}{l}\text { Educational } \\
\text { Building }\end{array}$ & 3 & 3 & $100 \%$ \\
\hline $\begin{array}{l}\text { Medical } \\
\text { Centre }\end{array}$ & 1 & 3 & $33.3 \%$ \\
\hline $\begin{array}{l}\text { Worship } \\
\text { Building }\end{array}$ & 2 & 3 & $66.6 \%$ \\
\hline $\begin{array}{l}\text { Commercial } \\
\text { Building }\end{array}$ & 5 & 12 & $41.7 \%$ \\
\hline Police station & 2 & 3 & $66.6 \%$ \\
\hline Lake & 1 & 6 & $16.7 \%$ \\
\hline
\end{tabular}

Table 11: Number of building features with correct attribute name

\section{CONCLUSION}

Despite the late emergence of OSM community in Malaysia compared to developed countries such as United Kingdom and French, this study has demonstrated that OSM dataset of Putrajaya Malaysia has good quality of road networks where 94\% of road networks that have been sampled were 100 percent overlapped when compared to the reference dataset. OSM datasets of Putrajaya have mapped many important features, such as police stations, medical centres, fire stations, multipurpose hall and worship buildings, although the number of building features is still low which less than $2 \%$. The correctness of thematic classification and features' names were found below than $50 \%$. Therefore, OSM is fairly suitable to be used as additional data for the Putrajaya area though more efforts should focus on mapping the building features and adding more attributes of features. The slow-paced progressing of OSM efforts in Malaysia is become a challenge as to increase the quality of OSM in Malaysia, it will depend on the number of OSM contributors concentration. The motivation to contribute need to be further explored as different cultures and socioeconomic particularly in developing countries influence the reason to involve in such volunteering efforts.

There are several limitations of this study. Due to the scope of assessment being limited to a Putrajaya dataset, the findings might not be able to represent for the overall quality of OSM for Malaysia. The assessment of quality was limited to four quality elements (i.e. relative positioning, usability, attributes and completeness). Future research is suggested to include other quality parameters, including temporal accuracy and logical consistency and consider the intrinsic quality evaluation for assessing VGI.
This study is significant with an expected contribution to the assessment of quality of VGI in developing countries that commonly facing slow-paced progress in mapping the OSM. The findings could be used as a basis for various parties that plan to use OSM in Malaysia, particularly Putrajaya as a supplementary data to authoritative sources, including data supplied by the professional surveyors.

\section{ACKNOWLEDGEMENTS}

The authors would like to thank Mrs. Suzana Abd Samad and the Perbadanan Putrajaya Malaysia for supplying the reference dataset. This project was supported by the Universiti Teknologi Malaysia and Ministry of Education Malaysia (GUP grant 17H13)

\section{REFERENCES}

Coote, A., and Rackham, L. 2008. "Neogeographic data quality-is it an issue". In AGI Geocommunity conference.

Esmaili, R., Naseri, F., and Esmaili, A. 2013. "Quality Assessment of Volunteered Geographic Information." American Journal of Geographic Information System 2, no. 2: 19-26

Girres, J. F., and Touya, G. 2010. "Quality assessment of the French OpenStreetMap dataset." Transactions in GIS 14, no. 4: 435-459.

Goodchild, M. F. 2007. "Citizens as sensors: The world of volunteered geography.” GeoJournal 69, no. 4: 211-221.

Goodchild, M. F., and Gary J. H. 1997. "A simple positional accuracy measure for linear features." International Journal of Geographical Information Science 11, no. 3: 299-306.

Haklay, M. 2008. "How good is OpenStreetMap information? A comparative study of OpenStreetMap and Ordnance Survey datasets for London and the rest of England." Environment and Planning B: Planning and Design.

Haklay, M. 2010. "How good is OpenStreetMap information? A comparative study of OpenStreetMap and Ordinance Survey datasets for London and the rest of England." Environ Planning B 37: 682-703.

Idris, Nurul Hawani, Mohamad Jahidi Osman, Kasturi Devi Kanniah, Nurul Hazrina Idris, and Mohamad Hafis Izran Ishak. 2017. "Engaging indigenous people as geo-crowdsourcing sensors for ecotourism mapping via mobile data collection: a case study of the Royal Belum State Park." Cartography and Geographic Information Science 44, no. 2: 113-127.

Idris, N.H.; Fauzi, M.F.; Osman, M.J; Ishak, M.H.I. 2016. Neogeography Platform for Flood Volunteers: A Reflection on the Malaysia 2014 Flood Disaster. Buletin GIS and Geomatik. Bil. 1. Jabatan Ukur dan Pemetaan Malaysia (JUPEM), Kuala Lumpur.

ISI19115. 2005. "Geographic information - metadata". 
ISO19157. 2013. "Geographic information -- Data quality Standard".

Jacobs, Clemens and Zipf, Alexander. 2017. "Completeness of citizen science biodiversity data from a volunteered geographic information perspective". Geo- spatial Information Science, 20:1, 3-13, DOI: 10.1080/10095020.2017.1288424

JPBD. 2007. "Bab 6: Infrastruktur Dan Utiliti”. Jabatan Perancangan Bandar dan Desa Selangor (JPBD) Retrieved on 8 June $2017 \quad$ from http://www.jpbdselangor.gov.my/Laporan/Manual_Garis_pandu an_piawaian_JPBDselangor/Manual-Garis-Panduan.pdf

Kounadi, O. 2009. "Assessing the quality of OpenStreetMap data." MSc Thesis, University College of London.

MaCGDI, 2010. Garis Panduan Penilaian Kualiti Data Geospatial: Malaysian Centre for Geospatial Data Infrastructure: Kuala Lumpur.

MyGeoportal. Retrieved on September 20, 2016 from http://www.mygeoportal.gov.my/

Neis, P., and Zielstra, D. 2014. "Recent Developments and Future Trends in Volunteered Geographic Information Research: The Case of OpenStreetMap." Future Internet 6, no. 1: $76-106$

Neis, P., Zielstra, D., and Zipf, A. 2012. "The Street Network Evolution of Crowdsourced Maps: OpenStreetMap in Germany 2007-2011”. Future Internet, 4: 1-21.

Neis, P., Zielstra, D., and Zipf, A. 2013. "Comparison of Volunteered Geographic Information Data Contributions and Community Development for Selected World Regions". Future Internet, 5: 282-300; doi:10.3390/fi5020282

Oort P. V. 2006. "Spatial Data Quality: From Description to Application". Dissertation PhD, Wageningen Universiteit

OpenStreetMap Wiki contributors. 2017. “2017 Mexico Earthquakes". Retrieved on 9 Oct 2017 from http://wiki.openstreetmap.org/w/index.php?title=2017_Mexico_ Earthquakes\&oldid $=1513516$

OSMStats. Retrieved on December 5, 2016 from http://osmstats.neis-one.org/

Saiful, M. A. 2012. "Penilaian Kualiti Data Terhadap OpenStreetMap”. BSc Thesis Universiti Teknologi Malaysia.

Seeger, C. J. 2008. "The role of facilitated volunteered geographic information in the landscape planning and site design process.” GeoJournal, 72, no. 3-4: 199-213.

Siebritz, Lindy-Anne. 2015. "Assessing the quality of OpenStreetMap data" ee Publishers. Retrieved on 8 June 2017 from http://www.ee.co.za/article/assessing-qualityopenstreetmap-data.html
Ushahidi. Retrieved on September 20, 2016 from www.Ushahidi.com

Zielstra, D., and Hochmair, H.H. 2011. Digital street data: Free versus proprietary. GIM Int., 25: 29-33.

Revised August 2018 